\title{
Respiratory electron transport system activity in symbiotic corals and its link to calcification
}

\author{
Sylvain Agostini ${ }^{15, *}$, Hiroyuki Fujimura ${ }^{1}$, Kazuhiko Fujita ${ }^{2}$, Yoshimi Suzuki ${ }^{3}$, \\ Yoshikatsu Nakano ${ }^{4}$

\begin{abstract}
${ }^{1}$ Department of Chemistry, Biology and Marine Science, University of the Ryukyus, 1 Senbaru, Nishihara-cho, Okinawa 903-0213, Japan

${ }^{3}$ Graduate School of Science and Technology, Shizuoka University, 836 Ohya, Suruga-ku, Shizuoka 422-8529, Japan
\end{abstract} \\ ${ }^{2}$ Department of Physics and Earth Science, University of the Ryukyus, 1 Senbaru, Nishihara-cho, Okinawa 903-0213, Japan \\ ${ }^{4}$ Sesoko Station, Tropical Biosphere Research Center, University of the Ryukyus, 3422 Sesoko, Motobu, Okinawa 905-0227, \\ Japan \\ ${ }^{5}$ Present address: Shimoda Marine Research Center, University of Tsukuba, 5-10-1 Shimoda, Shizuoka 415-0025, Japan
}

\begin{abstract}
Scleractinian corals host photosynthetic endosymbionts, making direct measurement of the host respiration rate via incubation methods based on $\mathrm{O}_{2}$ consumption impossible. We tested the use of the respiratory electron transport system activity (ETSA) for measuring host potential respiration. The applied method, modified from a previous study, is based on the reduction of (4-iodophenyl)-3-(4-nitrophenyl)-5-phenyl-2H-tetrazolium chloride (INT) to formazan. After the development of a protocol suitable for corals, the method was tested on 5 different species. Metabolism, including photosynthesis, dark respiration and light and dark calcification, was measured through incubation. Host and zooxanthellae fractions were separated and their ETSAs, protein contents and zooxanthellae densities were measured. Mean ETSA/dark respiration (ETSA/R) ratios for host corals ranged from $1.7 \pm 0.2$ to $3.5 \pm 0.6$, while ratios for zooxanthellae ranged from 3.7 to 7.8 . The high ratios observed for zooxanthellae indicate that their respiration may be 5 times higher under light conditions than in the dark. Considering the obtained ratios, host respiration in light could increase at most by a factor of 3.5 compared with dark respiration rates. Ratios close to 1 were found for some specimens, which suggests that higher respiration rates under light compared with dark conditions are not possible. Therefore, increased respiration in light cannot explain the observed enhancement of calcification under light conditions. ETSA was correlated with zooxanthellae density, suggesting adaptation of the levels of host ETS enzymes to the amount of translocated photosynthetates under optimal conditions. Estimated dark host respiration was correlated with photosynthesis, which suggests that it is determined mainly by the amount of energy available but also the amount of electron transport system enzymes. This constrains the amount of ATP available for calcification. Hence, we propose a mechanism by which respiration limits the calcification rate.
\end{abstract}

KEY WORDS: Electron transport system · ETS · Respiration · Calcification · Symbiotic corals Resale or republication not permitted without written consent of the publisher

\section{INTRODUCTION}

Respiration measurements are usually based on $\mathrm{O}_{2}$ consumption, but such measurements have important limitations. In the case of laboratory experiments, stresses due to the incubation conditions required for measurement may affect the respiration rates of the studied organisms. To overcome the limitations of these methods, indirect biochemical techniques have been developed. However, to the best of our knowledge, such methods have never been used in symbiotic organisms. Corals are symbiotic organisms that 
host photosymbionts known as zooxanthellae, which is the name given to a wide array of different algae of the genus Symbiodinium.

The biochemical methods proposed for conducting respiratory measurements include the quantification of respiratory electron transport system activity (ETSA) (Packard 1971), which was later modified by Owens \& King (1975). This method measures the activities of the enzymes that constitute the electron transport system (ETS) at saturated substrate concentrations. Therefore, ETSA represents the potential respiratory rate and has been used to estimate oxygen consumption in various environments and community assemblages, including sediment meiofauna (Olanczukneyman \& Vosjan 1977, Broberg 1985, Relexans 1996a,b), plankton (Kenner \& Ahmed 1975a, Owens \& King 1975, Packard et al. 1975, Bamstedt 1980, Hernández-Leó \& Gómez 1996) and marine invertebrates (Cammen et al. 1990, St-Amand et al. 1999, Martínez et al. 2010). The method proposed by Packard in 1971 and modified for application to corals in the present study is based on the reduction of an artificial substrate, 2-(4-iodophenyl)-3-(4-nitrophenyl)-5-phenyl-2H-tetrazolium chloride (INT), by the coenzyme Q cytochrome- $b$ complex. The mitochondrial and microsomal ETSs are saturated with substrates, and the reduction of INT to formazan is followed by spectrophotometry. The transfer of electrons between the coenzyme Q cytochrome- $b$ complex and complex III or INT is known to be the ratelimiting step in the electron transport chain (Packard 1971). Therefore, ETSA represents the maximum potential respiration, which is assumed to be correlated with the maximum potential ATP production. Finally, ETSA measurements present the advantage of removing problems due to the stressful conditions during the confinement required for measurement with traditional methods, which can confound the obtained respiration rates. To apply the ETSA method to the coral holobiont system, a suitable protocol must be developed that will allow the measurement of the ETSAs of the different components, i.e. the host and the zooxanthellae.

Corals and other calcifying organisms that harbor photosymbionts or are themselves photosynthetic show strong coupling between calcification and photosynthesis at the organismal and community levels. Increased calcification is commonly known to occur under light in photosynthetic organisms; this phenomenon is referred to as light-enhanced calcification. The calcification rates in corals are on average 3 times higher in the light than in the dark (Gattuso \& Allemand 1999, Goreau 1959, Barnes \& Chalker
1990), and have been reported to be 6 to 10 times higher in the light for the coral Stylophora pistillata (Houlbreque et al. 2004). Several hypotheses (see Gattuso \& Allemand 1999 for a review) have been proposed to explain this enhancement, but the interactions between calcification and photosynthesis remain unresolved and are a matter of continuous controversy (McConnaughey et al. 2000, Gattuso et al. 2000), with some arguing that repression of calcification occurs during night (Marshall 1996). The most recent hypothesis is based on the titration of protons $\left(\mathrm{H}^{+}\right)$produced by calcification with hydroxyl ions $\left(\mathrm{OH}^{-}\right)$produced during the photosynthetic process (Furla et al. 1998, 2000, Moya et al. 2006). Some of the recurrent hypotheses that have been put forth to explain this phenomenon are as follows: removal of metabolites as phosphate compounds that may inhibit calcification (Simkiss 1964); removal of $\mathrm{CO}_{2}$, shifting the chemical equilibrium of calcification towards the formation of calcium carbonates (Goreau 1959); and provision of photosynthetates used for the construction of the organic matrix or as an energy source that is then used for calcification (Barnes \& Taylor 1973, Barnes \& Chalker 1990, McConnaughey et al. 2000). As ATP produced by the zooxanthellae cannot be used directly by the coral host, translocated photosynthetates need to be converted to ATP by the host itself through aerobic respiration. Therefore, the light enhancement of calcification due to the translocation of photosynthetates during the day should involve higher respiration rates than during the night.

An increase of respiratory rates under light that could be linked to the enhancement of calcification was observed by Al-Horani et al. (2003) using microsensors. Employing the same technique, higher respiration rates have been found for photosynthetic organisms (Jørgensen et al. 1985), including coral holobionts (Kühl et al. 1995). However, this method requires microsensors with specific characteristics (response time $<1 \mathrm{~s}$ ) that are difficult to acquire. It may also be biased, as the respiration of the holobiont as a whole is measured, even if only the host respiration is of interest. By measuring the ETSAs of the host and zooxanthellae separately, we can assess their potential respiratory rates. This potential can be compared with the actual respiration in the dark, making it possible to determine whether coral hosts exhibit the ETS that is required to increase their respiration rate in the light and if it can therefore explain the phenomenon of light-enhanced calcification. Moreover, higher respiration rates in the light have strong implications for coral physiology, rang- 
ing from carbon budgets to calcification. Thus, knowing how much of the organic carbon produced by zooxanthellae is actually consumed by the host through respiration is essential to the understanding of coral carbon and energy budgets. Therefore, it is important to develop new techniques to assess the respiration of the holobiont system in the light and in the dark.

The ETSA technique has been widely used to estimate the respiration of plankton in situ, but a ratio or algorithm is required for conversion to in vivo respiration. ETSA/respiration (ETSA/R) ratios can be determined for isolated zooxanthellae. It is possible to estimate the amount of respiration to be attributed to zooxanthellae by measuring the zooxanthellae ETSA of a coral holobiont and the associated ETSA/R ratios. Therefore, coral host respiration can also be calculated, which will allow investigation of the relationship between host respiration and calcification.

A protocol suitable for the measurement of the ETSA of the coral holobiont and its different components, i.e. the host and the zooxanthellae, was developed. Using this protocol, we investigated whether the coral host shows higher respiration rates under light that may explain the enhancement of calcification in the light. To test this hypothesis, we compare the ETSA/R ratios of different species of coral hosts. Finally, the link between photosynthesis, ETSA, respiration and calcification is discussed.

\section{MATERIALS AND METHODS}

\section{Study species}

Colonies of Galaxea fascicularis, Porites cylindrica, Pocillopora damicornis, Montipora digitata and massive Porites sp. were collected from a coastal region off Okinawa Island, Japan, with permission from the Okinawa Prefecture government (no. 23-7). The colonies were fractionated to obtain small fragments, and were maintained for several months in an outdoor aquarium with running seawater at the Sesoko Station, Tropical Biosphere Research Center, University of the Ryukyus, Okinawa, Japan. A month before measurements were performed, the coral colonies were transferred to an indoor aquarium with a $12 \mathrm{~h}$ : $12 \mathrm{~h}$ light:dark cycle. The water in the aquarium (15 l) was replaced every week with fresh seawater, replacing half of the water every 3 to $4 \mathrm{~d}$. The aquarium only contained the specimens ( $n=5$ to 7$)$ of one species at a time.

\section{Host-zooxanthellae separation, homogenization and enzyme extraction for ETSA assays}

To measure ETSA in coral hosts and zooxanthellae, the 2 fractions need to be separated and homogenized to extract the ETS. Both steps need to be conducted while preserving enzyme activity. Finally, the assay conditions have to be adapted to the enzyme properties of the coral host and zooxanthellae. To develop a suitable protocol for corals, colonies of Galaxea fascicularis were used.

Separation of the host and zooxanthellae fractions

Coral tissues were removed using an airjet filled with ice-cold $50 \mathrm{mmol} \mathrm{l}^{-1}$ phosphate buffer containing $10 \mathrm{~g} \mathrm{l}^{-1} \mathrm{NaCl}$. The resulting slurry was first slightly homogenized by applying 5 strokes in a Teflon homogenizer. Then, it was centrifuged at $414 \times g$ for $20 \mathrm{~min}$ to separate the host and zooxanthellae fractions. The pellet containing the zooxanthellae fraction was re-suspended in saline phosphate buffer, and the centrifugation step was repeated 3 times, after which no activity was detected in the supernatant.

\section{Extraction and preparation of the ETS for assays}

Cell-free extracts can be obtained through mechanical action, such as bead beating or grinding, or via sonication to break up cells and mitochondria to release enzymes. Both methods were tested. Different durations of sonication were tested (1 to $20 \mathrm{~min}$ ) with the power of the sonicator (Smurt NR-50 M, Microtec) set at $25 \%$ in one fraction each from the host and zooxanthellae. The effects of the presence of the commonly used chemicals polyvinylpyrrolidone K30 (PVP) at $1.5 \mathrm{mg} \mathrm{ml}^{-1}$ (Wako Pure Chemical Industries), $\mathrm{MgSO}_{4}$ at $75 \mu \mathrm{mol} \mathrm{l} \mathrm{l}^{-1}$ (Wako Pure chemical Industries), Triton-X at $0.20 \%$ (TritonX100, Sigma Aldrich) and EDTA 2Na at $10 \mathrm{mmol} \mathrm{l}^{-1}$ (Kanto Chemical) were also investigated in both the host and zooxanthellae fractions. The treatment containing PVP at $1.5 \mathrm{mg} \mathrm{ml}^{-1}, \mathrm{MgSO}_{4}$ at $75 \mu \mathrm{mol} \mathrm{l}^{-1}$ and Triton $\mathrm{X}$ at $0.20 \%$, which is the composition recommended by Packard et al. (1975), was used as the control treatment, and its ETSA was fixed at $100 \%$. The activities obtained under other treatments, omitting $\mathrm{PVP}, \mathrm{MgSO}_{4}$ or Triton $\mathrm{X}$ or adding EDTA to the buffer used in the control treatment, were expressed as the percentage of activity com- 
pared with the control treatment. ANOVA followed by a Dunnett's test was used to assess the differences between the different homogenization buffers. The $\mathrm{R}$ software package (R Development Core Team 2011) was used to perform these tests.

After homogenization, the homogenates were cleared via centrifugation at $10000 \times g$ for $5 \mathrm{~min}$. While this step is not required for host fractions, it reduced the turbidity blank of the zooxanthellaecontaining fractions, without affecting their activities. All steps were conducted on ice or in a cooling centrifuge at $3^{\circ} \mathrm{C}$.

\section{Optimization of the ETSA assay}

\section{Substrate concentrations}

To measure the maximum enzymatic rate $\left(V_{\max }\right)$, substrates should be at saturation concentrations. The saturation concentrations reported in the literature range from 0.835 to $1 \mathrm{mmol} \mathrm{l}^{-1}$ for $\mathrm{NADH}$, from 0.15 to $0.25 \mathrm{mmol} \mathrm{l}^{-1}$ for NADPH and from 0 to $133 \mathrm{mmol} \mathrm{l}^{-1}$ for succinate. As these concentrations were adjusted mainly for plankton, investigations of the concentration kinetics of the host and zooxanthellae fractions were performed. All ETSA measurements were carried out within $2 \mathrm{~h}$ of homogenization. The optimum concentrations and saturation concentrations of the substrates were investigated in 3 different colonies of the model species Galaxea fascicularis. Under the assumption that the reduced form of NADH is the main substrate for mitochondrial ETS, while the reduced form of NADPH is the main substrate for microsomal ETS, we studied their kinetics by adding different concentrations of these substances to the assays. In addition, succinate, an initial electron donor in the mitochondrial ETS, was added to saturated NADH and NADPH concentrations. The tested concentrations were $0-3 \mathrm{mmol} \mathrm{l}^{-1} \mathrm{NADH}$ (Wako Pure Chemicals), 0-0.3 $\mathrm{mmol} \mathrm{l}^{-1} \mathrm{NADPH}$ (Wako Pure Chemicals) and 0-300 mmol l-1 succinate (disodium succinate, anhydrous, Wako Pure Chemicals). The concentration of INT (Wako Pure Chemicals) was $0.4 \mathrm{mg} \mathrm{ml}^{-1}$, as indicated in Packard (1971). Higher and lower INT concentrations were also tested, but the chemical blank increased too greatly at higher concentrations, without a detectable increase in activity. The reactions were stopped using a solution of $50 \%$ formalin after $20 \mathrm{~min}$. The absorbance was read immediately at $490 \mathrm{~nm}$ in a UV-Vis spectrophotometer (U-2001, Hitachi). The obtained substrate kinetics were fitted against a nonlinear model based on the Mickaelis-Menten equation.
Length of incubation and linearity of the reaction

To determine the optimal incubation length, the absorbances in 3 samples were followed continuously. The linearity in function of the activities of the samples was tested in 3 extracts by increasing the volume of extract used in the assay. The tested volume ranged from 0 to $600 \mu \mathrm{l}$. For volumes less than $300 \mu \mathrm{l}$, the extract was diluted to a volume of $300 \mu \mathrm{l}$ using saline phosphate buffer. For volumes greater than $300 \mu \mathrm{l}$, the volume of buffer used for dilution of the substrates was reduced to maintain the same final assay volume $(1.6 \mathrm{ml})$. The reaction was incubated for $20 \mathrm{~min}$ and stopped with $50 \%$ formalin $(1 \mathrm{ml})$.

\section{Temperature and $\mathrm{pH}$ effects}

The effects of $\mathrm{pH}$ and temperature were tested in 3 different colonies, one from each of Galaxea fascicularis, Montipora digitata and Porites cylindrica. Incubations were conducted at room temperature (ca. $25^{\circ} \mathrm{C}$ ) and in a temperature-controlled water bath to study the variation in activity with temperature. All solutions were prepared in phosphate buffer (with the exception of INT, which was prepared in MilliQ water) at $50 \mathrm{mmol} \mathrm{l}^{-1}$ and adjusted to $\mathrm{pH} 8.5$ or a $\mathrm{pH}$ ranging from 7.0 to 9.0 to study the effects of $\mathrm{pH}$. The $\mathrm{pH}$ of the phosphate buffer was adjusted using $\mathrm{NaOH}$ or $\mathrm{HCl}$. The effect of temperature on the reaction kinetics was investigated in a temperature range from $10^{\circ} \mathrm{C}$ to $40^{\circ} \mathrm{C}$. The variation in activity with temperature was fitted against the Arrhenius law using Qtiplot software (http://soft.proindependent.com/ qtiplot.html). The energy of the activation constant $\left(E_{a}\right)$ for the reactions was determined by nonlinear fitting.

\section{Calculation of the ETS activities}

The volumes of the substrate solution (containing $\mathrm{NADH}$, NADPH and/or succinate) and cell-free extract used in the protocol were $1 \mathrm{ml}$ and $300 \mu \mathrm{l}$, respectively. The reaction was started with $300 \mu$ of INT and stopped with $1 \mathrm{ml}$ of $50 \%$ formalin. The increase in absorbance was linear over 20 min at the temperature tested $\left(25^{\circ} \mathrm{C}\right)$, and all subsequent samples were therefore incubated for $20 \mathrm{~min}$. The absorbance of each sample was corrected using a turbidity blank $(300 \mu \mathrm{l}$ cell-free extract and $2.3 \mathrm{ml}$ phosphate buffer) and a chemical blank, where the cell-free extract was replaced by a solution of phos- 
phate buffer and homogenization buffer, as indicated in Packard (1971). Changes in absorbance were converted into ETSA expressed in $\mathrm{mg} \mathrm{O}_{2} \mathrm{~h}^{-1} \mathrm{mg}^{-1}$ protein using the following formula:

$$
\mathrm{ETSA}=\frac{A}{\varepsilon_{490}} \times \frac{\mathrm{V}_{\mathrm{a}}}{t} \times \frac{1}{2} \times M \times \frac{D}{\mathrm{~V}_{\mathrm{s}} C_{\text {prot }}}
$$

where $A$ is the corrected absorbance at $490 \mathrm{~nm} ; \varepsilon_{490}$ is the molar extinction coefficient, which is $15.9 \mathrm{l}$ $\mathrm{mmol}^{-1} \mathrm{~cm}^{-1}$ in $0.16 \%$ Triton X (Kenner \& Ahmed $1975 a) ; t$ is the incubation time of the assay in hours (here $t=1 / 3 \mathrm{~h}) ; \mathrm{V}_{\mathrm{a}}$ is the final volume of the assay $\left(\mathrm{V}_{\mathrm{a}}=2.6 \mathrm{ml}\right) ; M$ is the molecular mass of $\mathrm{O}_{2}(M=32)$; $D$ is the dilution applied to the sample; $V_{\mathrm{s}}$ is the volume of sample used in the assay $\left(\mathrm{V}_{\mathrm{s}}=0.3 \mathrm{ml}\right)$; and $C_{\text {prot }}$ is the concentration in protein of the homogenate in $\mathrm{mg} \mathrm{ml}^{-1}$. A fraction of $1 / 2$ is required to convert the reduction of INT into $\mathrm{O}_{2}$, as 2 moles of INT is electrochemically equivalent to 1 mole of $\mathrm{O}_{2}$. For our assay, the formula becomes:

$$
\mathrm{ETSA}=7.85 \times A \times \frac{D}{\mathrm{~V}_{\mathrm{s}} C_{\text {prot }}}
$$

\section{Application of the ETSA assay and metabolic measurements}

Respiration rates and ETSAs of isolated zooxanthellae

Colonies of Galaxea fascicularis, Porites cylindrica, Pocillopora damicornis, Montipora digitata and massive Porites sp. were used in this experiment. The respiration rates and ETSAs were measured in isolated zooxanthellae from 2 colonies of each species $(n=10)$. For respiration measurements, zooxanthellae were isolated from a coral tissue slurry obtained from half a colony using an airjet with filtered seawater. After 3 consecutive washes via repeated centrifugation/re-suspension in filtered seawater, approximately $5 \mathrm{ml}$ of the obtained zooxanthellae suspension was placed in a stirred, airtight micro-chamber fixed on a luminescence-based dissolved oxygen (RDO) probe (Orion 4 stars, Thermo Scientific). The suspension was incubated for a minimum of $30 \mathrm{~min}$, or until dissolved oxygen reached $\sim 9 \mathrm{mg} \mathrm{l}^{-1}$, under white LED light at $50 \mu \mathrm{mol}$ photons $\mathrm{s}^{-1} \mathrm{~m}^{-2}$. The suspension was then placed in the dark. Respiration was calculated from the consumption of dissolved oxygen during the first $20 \mathrm{~min}$ in the dark. Zooxanthellae abundances were determined by counting individual cells in a hemocytometer. Respiration rates were expressed in $\mathrm{mg}$ $\mathrm{O}_{2} \mathrm{~h}^{-1} \mathrm{zoox}^{-1}$.
To measure the ETSA per zooxanthellae, tissues from the remaining halves of the colonies were removed using an airjet with saline phosphate buffer. The ETSA and zooxanthellae abundances in this slurry were determined using the optimized methods. The ETSAs were expressed in $\mathrm{mg} \mathrm{O}_{2} \mathrm{~h}^{-1} \mathrm{zoox}^{-1}$. These activities and the respiration rates measured in the micro-chamber were used to calculate the ETSA/R ratio for the zooxanthellae. The average of all samples $(n=10)$ was used in later analyses.

Measurement of the metabolic rates of whole colonies

Colonies of Galaxea fascicularis, Porites cylindrica, Pocillopora damicornis, Montipora digitata and massive Porites sp. were incubated in freshly collected seawater at Sesoko Station, Okinawa, Japan, at room temperature (ca. $25^{\circ} \mathrm{C}$ ) for $3 \mathrm{~h}$ in light (metal halides, $150 \mu \mathrm{mol}$ photons $\mathrm{s}^{-1} \mathrm{~m}^{-2}$, measured with a LiCor quantum sensor) and $2 \mathrm{~h}$ in the dark in individual vessels. The metabolic rates in terms of photosynthesis, dark respiration and calcification were measured for each colony. The dissolved oxygen and $\mathrm{pH}$ were measured at the beginning and end of each incubation using an Orion 4-Star pH-DO sensor equipped with an RDO probe and a pH electrode (8156 BNUWP, Thermo Scientific) calibrated to a seawater scale. Sub-samples of the incubation water were sampled at the beginning and end of each incubation period and filtered through a $0.45 \mu \mathrm{m}$ membrane filter to measure total alkalinity. Total alkalinity was determined via titration with $\mathrm{HCl}$ at $0.1 \mathrm{~mol}^{-1}$ with a Metrohm titrator (785 DMP titrino). Calcification rates were calculated using the alkalinity anomaly method (Gattuso et al. 1996), and photosynthesis and respiration were calculated based on the variation in dissolved oxygen during the light and dark incubations, respectively. The photosynthesis rates presented here are therefore net photosynthesis rates. The protein contents and zooxanthellae densities were determined via the Bradford method and by counting cells in the tissue slurry using a hemocytometer (Neubauer modified), respectively. The ETSAs of the total and the zooxanthellae fractions were measured using the optimized protocol.

Calculations and expression of the results

Coral metabolic rates, including those associated with photosynthesis, calcification, total respiration (dark) and zooxanthellae, were expressed relative to 
milligrams of host protein. ETSAs were expressed in $\mathrm{mg} \mathrm{O}_{2} \mathrm{~h}^{-1} \mathrm{mg}^{-1}$ protein, whether for the host or zooxanthellae, as shown in Eq. (1). The host ETSA was calculated as the difference between the holobiont ETSA (before zooxanthellae separation) and the zooxanthellae ETSA, as the recovery of the host ETSA after separation via centrifugation was low. The zooxanthellae ETSA of the whole colony was calculated. Then, the zooxanthellae ETSA was converted to zooxanthellae respiration, the total $\mathrm{O}_{2}$ consumption of the zooxanthellae, using the average of the ETSA/R ratios for all species (2 specimens per species) obtained in the experiment with isolated zooxanthellae. Host respiration was calculated from the difference between the zooxanthellae respiration and the $\mathrm{O}_{2}$ consumption in the dark for the whole colony measured during the incubation of the corals. The correlations between the different metabolic rates and parameters were determined via the least-squares methods.

\section{RESULTS}

\section{ETS extraction: homogenization technique and buffer}

Several methodological tests were conducted to optimize the homogenization procedure. Bead beating was compared with sonication, but the obtained ETSA recovery was only $20 \%$, and this method was soon discarded. Different sonication durations were tested for both the host and zooxanthellae fractions. The power of the sonicator was adjusted to $25 \%$ when the volume of homogenate was $5 \mathrm{ml}$ because under a higher power foam formed, which may re-

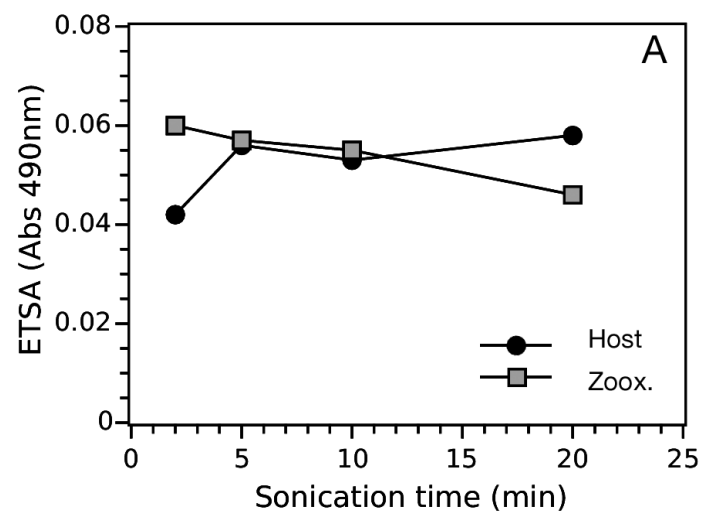

duce the measured activity (Packard et al. 1975). Maximum zooxanthellae activity was obtained after $2 \mathrm{~min}$ of sonication and decreased with time (Fig. 1A). Host activity reached a maximum after $5 \mathrm{~min}$. As the difference in the zooxanthellae activity after 2 and 5 min was small, a sonication length of 5 min was chosen for both the zooxanthellae and host fractions.

The tests using different extraction buffers revealed that both the host and zooxanthellae ETSAs were significantly decreased when PVP was omitted from the homogenization buffer ( $\mathrm{p}=0.0254$ and 0.0387 , respectively, $\mathrm{n}=3$, Dunnett's test, omission of PVP vs. control; Fig. 1B). The addition of EDTA at a final concentration of $10 \mathrm{mmol} \mathrm{l}^{-1}$ did not affect the zooxanthellae ETSA ( $\mathrm{p}>0.05, \mathrm{n}=3$, Dunnett's test, addition of EDTA vs. control), but host activity was significantly increased $(p=0.0142, n=3$, Dunnett's test, addition of EDTA vs. control). The other treatments (omission of $\mathrm{MgSO}_{4}$ and omission of Triton X) did not affect the activities of either component when compared with the control solution ( $\mathrm{p}>0.05, \mathrm{n}=3$, Dunnett test).

\section{Optimal assay conditions}

\section{Substrate concentrations, incubation length and} linearity of the assay

The substrate kinetics of both the host and zooxanthellae ETSs follow Michaelis-type kinetics with regard to $\mathrm{NADH}$, showing a linear increase of the velocity as a function of the NADH concentration for the lowest concentrations and reaching a plateau at concentrations higher than $1 \mathrm{mmol} \mathrm{l}^{-1}$ (Fig. 2). Hence, the kinetics were fitted using the Michaelis-

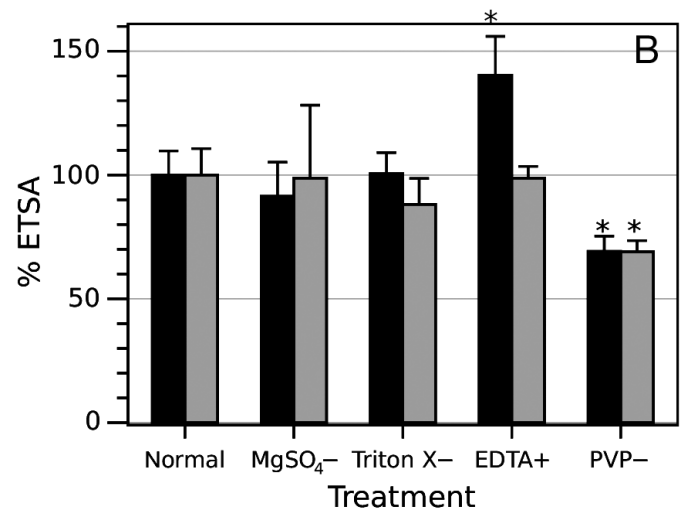

Fig. 1. (A) Variations in ETSA as a function of sonication time for the host and zooxanthellae fractions. (B) Effect of the addition of different components to the homogenization buffer on the host (black bars) and the zooxanthellae (grey bars) fractions. Normal indicates the control treatment, in which $\mathrm{MgSO}_{4}, \mathrm{PVP}$, and Triton X are present. $\mathrm{MgSO}_{4}-$, Triton X-, and PVP-indicate the treatments where each of the compounds was omitted, and EDTA+ represents the treatment where 10 mmol $\mathrm{l}^{-1}$ EDTA was added to the normal buffer. Error bars indicate SD $(n=3)$. Asterisk indicates a significant difference compared to the normal treatment

(Dunnett's test, $\mathrm{n}=3, \mathrm{p}<0.05$ ) 

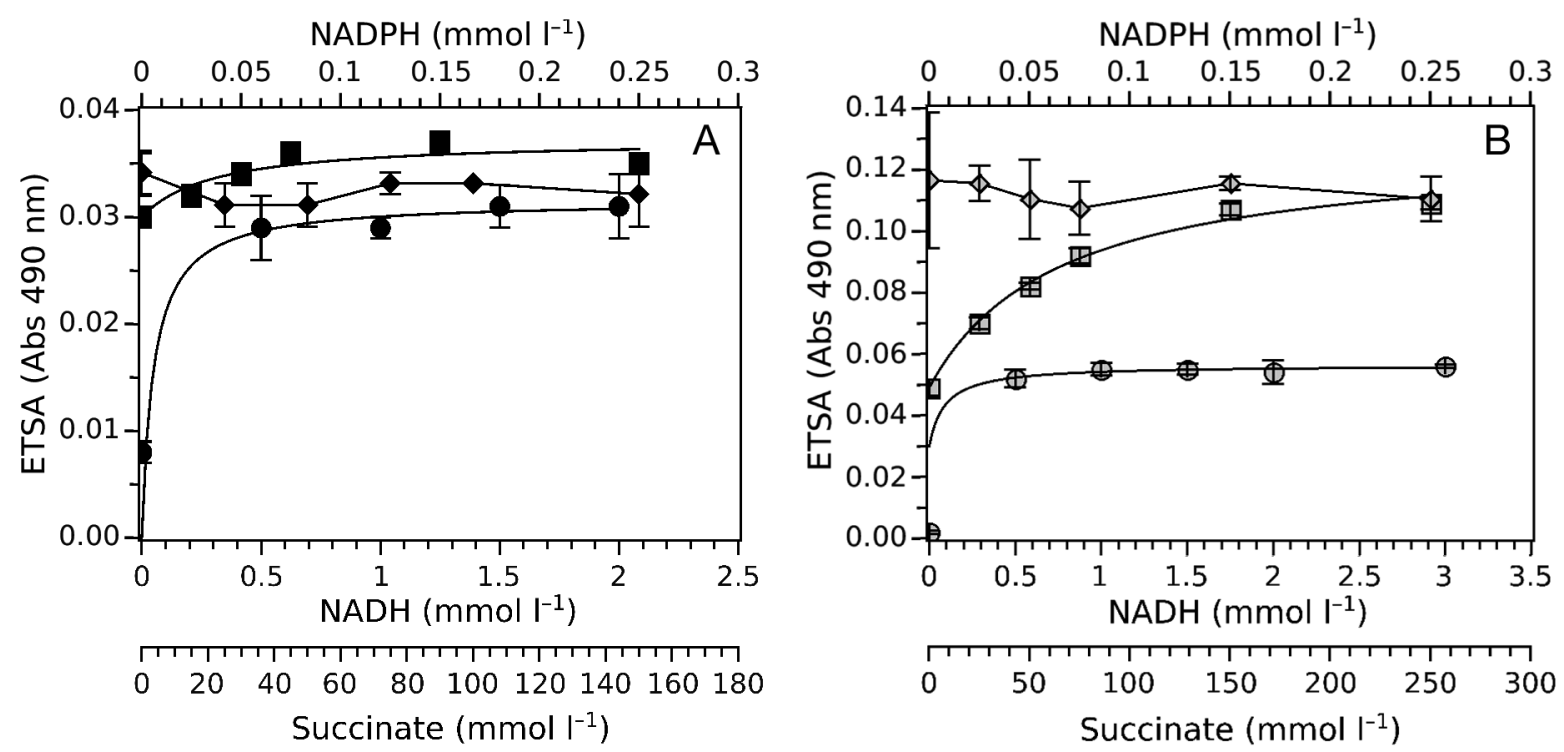

Fig. 2. Substrate kinetics of the ETS of (A) the coral host and (B) zooxanthellae. NADH (circles) and NADPH (squares) curves were fitted using the Michaelis-Menten equation. Succinate symbols (diamonds) are connected with straight lines. Error bars indicate SD $(n=3)$. NADPH was added to a saturated NADH concentration $\left(2 \mathrm{mmol} \mathrm{l}^{-1}\right)$ and succinate to saturated NADH and NADPH concentrations $\left(2 \mathrm{mmol} \mathrm{l}^{-1}\right.$ and $0.15 \mathrm{mmol}^{-1}$, respectively)

Menten equation, and the characteristics of the enzyme, apparent Michaelis constant $\left(K_{\mathrm{m}}\right)$ and $V_{\max }$ were calculated. The apparent $K_{\mathrm{m}}$ for $\mathrm{NADH}$ in the host fraction was $0.049 \mathrm{mmol} \mathrm{l}^{-1}$, and the minimum saturated concentration was estimated to be $1.5 \mathrm{mmol}$ $\mathrm{l}^{-1}$. The zooxanthellae fraction exhibited a lower apparent $K_{\mathrm{m}}$ of $0.038 \mathrm{mmol} \mathrm{l}^{-1}$, and a $1 \mathrm{mmol} \mathrm{l}^{-1} \mathrm{con}-$ centration could be considered saturated. The addition of $0.15 \mathrm{mmol} \mathrm{l}^{-1} \mathrm{NADPH}$ to a saturated concentration of NADH $\left(1.5 \mathrm{mmol} \mathrm{l}^{-1}\right)$ more than doubled the zooxanthellae activity, increasing it by $118 \%$ compared with using NADH alone. The addition of $0.15 \mathrm{mmol} \mathrm{l}^{-1} \mathrm{NADPH}$ increased the host ETSA by only $20 \%$. The addition of succinate did not increase the ETSA in either fraction, and the ETSA was slightly reduced in the host fraction at the highest succinate concentrations. According to these results, the final substrate mixture used contained NADH at $1.5 \mathrm{mmol} \mathrm{l}^{-1}$ and NADPH at $0.15 \mathrm{mmol} \mathrm{l}^{-1}$.

At these concentrations, the reactions were linear for $20 \mathrm{~min}$. The measured activity was proportional to the amount of homogenate $\left(\mathrm{r}^{2}=0.992, \mathrm{p}<0.01\right.$ and $\mathrm{r}^{2}=0.999, \mathrm{p}<0.01$ for the host and zooxanthellae, respectively; Fig. 3).

\section{Temperature and $\mathrm{pH}$}

The ETSA at $25^{\circ} \mathrm{C}$ was fixed as $100 \%$ for all specimens, and other activities were expressed as the percentage of the activity at $25^{\circ} \mathrm{C}$. The activity showed an exponential increase with temperature until $40^{\circ} \mathrm{C}$, which was the maximum temperature tested. The variation in activity with temperature fits the Arrhenius law well, with $\mathrm{r}^{2}=0.9508$ for the host fraction and $\mathrm{r}^{2}=0.9149$ for the zooxanthellae (Fig. 4A). The host ETS presented an $E_{\mathrm{a}}$ of $47.2 \mathrm{~kJ} \mathrm{~mol}^{-1}$, and the zooxanthellae constant was $30.3 \mathrm{~kJ} \mathrm{~mol}^{-1}$. The optimal $\mathrm{pH}$ was found to be approximately 8.5 for both the host and the zooxanthellae fractions, and ETSA was therefore fixed as $100 \%$ at $\mathrm{pH} 8.5$. The activity of the ETS increased at $\mathrm{pH}$ levels between 7.5 and 8.5 for both the host and zooxanthellae fractions. It

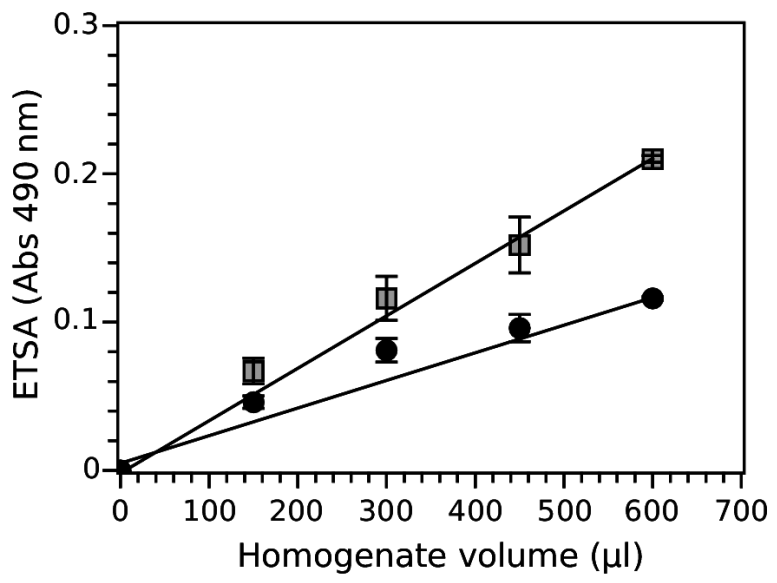

Fig. 3. Increase in ETSA of the xooxanthellae (grey squares) and host (black circles) fractions as a function of the volume of homogenate used. Straight lines represent the best fit by the least square methods for volumes ranging between 0 and $600 \mu \mathrm{l}$. Error bars indicate SD (n = 3) 

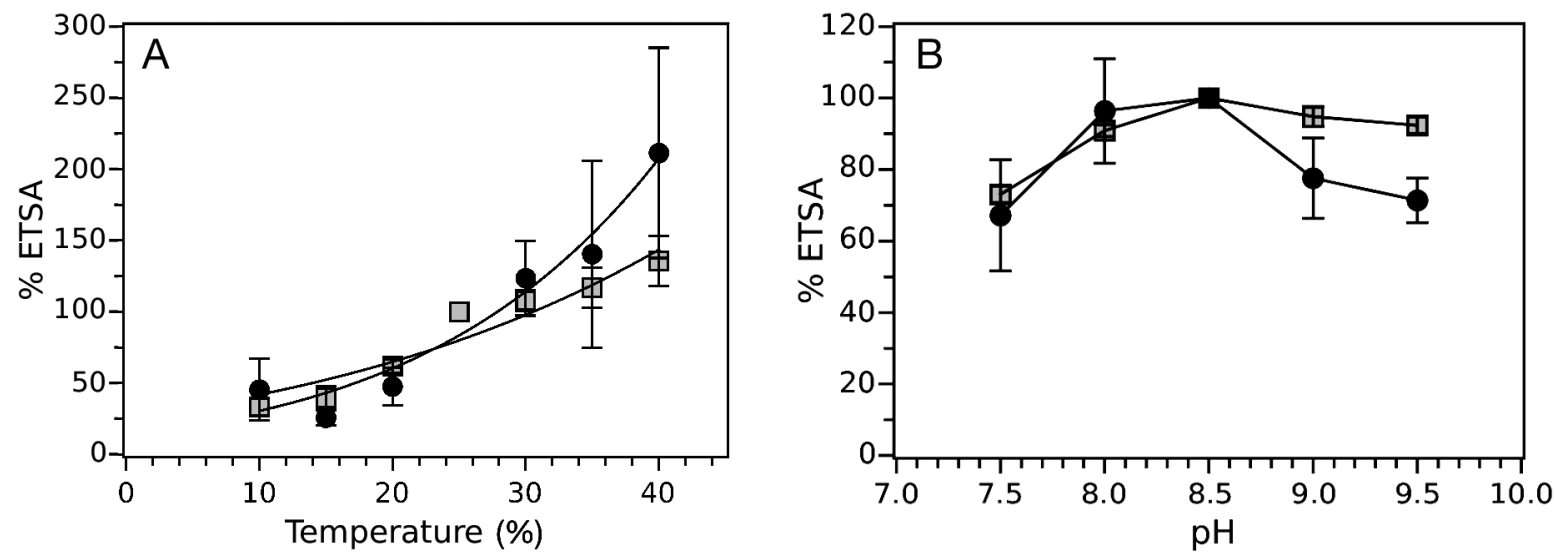

Fig. 4. Variations in ETSA as a function of (A) temperature and (B) pH for zooxanthellae (grey squares) and host (black circles) fractions. Error bars indicate SD $(n=3)$. Temperature curves were fitted using the Arrhenius law, and pH values are connected with straight lines

decreased at the higher $\mathrm{pH}$ levels tested, up to 9.5, especially for the host fraction (Fig. 4B).

\section{Application to coral colonies}

\section{Respiration and ETSA of isolated zooxanthellae}

The respiration rates of freshly isolated zooxanthellae were only measurable in filtered seawater. Zooxanthellae isolated in phosphate buffer did not show any detectable $\mathrm{O}_{2}$ consumption. Therefore, ETSAs and respiration were measured in 2 fragments from each of the examined coral colonies. The respiration measurements showed an almost linear decrease in oxygen during the initial $20 \mathrm{~min}$ after darkening (Fig. 5). The slope of the decrease was used as the respiration rate. The respiration rates ranged between 3.3 and $9.4 \mathrm{ng} \mathrm{O}_{2} \mathrm{~h}^{-1} 1000$ zoox $^{-1}$ among all coral species $(\mathrm{n}=10)$. The ETSA per zooxanthellae ranged from 25.8 to $35.5 \mathrm{ng} \mathrm{O}_{2} \mathrm{~h}^{-1} 1000 \mathrm{zoox}^{-1}(\mathrm{n}=10)$. The resulting ETSA/R ratio was $5.2 \pm 1.3(\mathrm{n}=10)$ on average and ranged between 3.7 and 7.8 , with the maximum ratio obtained for zooxanthellae isolated from Galaxea fascicularis and the minimum for zooxanthellae isolated from Pocillopora damicornis (Table 1).

\section{ETSA and metabolism of coral holobionts}

Because the water temperatures during the respiration measurements and ETSA assays were the same $\left(25^{\circ} \mathrm{C}\right)$, no temperature correction was needed. The zooxanthellae exhibited a significantly higher ETSA per mg of protein than the hosts, with values ranging from $5.41 \pm 0.66$ to $12.37 \pm 2.40 \mathrm{mg} \mathrm{O}_{2} \mathrm{~h}^{-1}$ $\mathrm{mg}^{-1}$ zoox protein, compared with $0.88 \pm 0.18$ to $4.68 \pm 0.67 \mathrm{mg} \mathrm{O}_{2} \mathrm{~h}^{-1} \mathrm{mg}^{-1}$ host protein for the host. For calculation of zooxanthellae respiration, we used an ETSA/R of 5.2, the average for all species examined in the isolated zooxanthellae experiment. Zooxanthellae respiration accounted for less than $40 \%$ of the total respiration, with the exception of Pocillopora damicornis, for which zooxanthellae respiration represented $54 \%$ of the total respiration. Host respiration, or the $\mathrm{O}_{2}$ consumption accounted for by the host, ranged from $0.26 \pm 0.06$ (P. damicornis) to $1.39 \pm$ $0.23 \mathrm{mg} \mathrm{O}_{2} \mathrm{~h}^{-1} \mathrm{mg}^{-1}$ host protein (Galaxea fascicularis) (Table 2). The host species G. fascicularis,

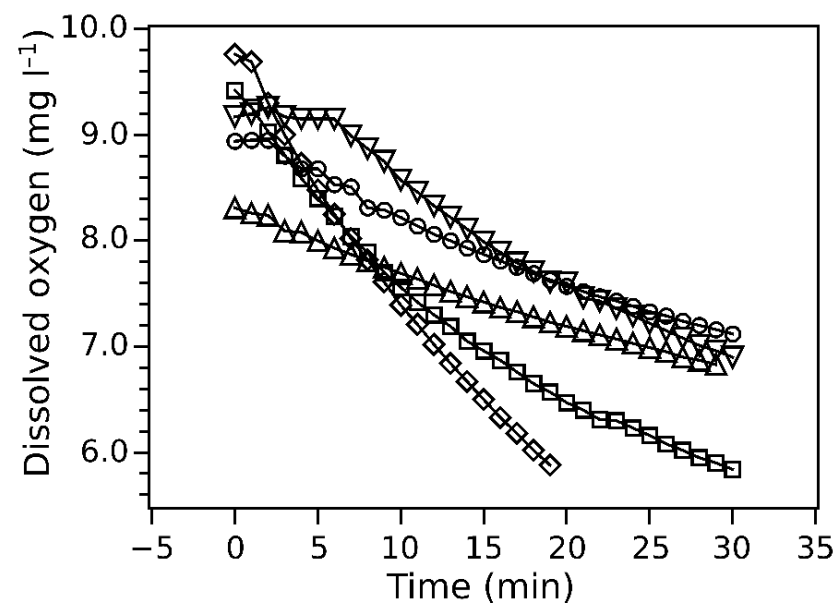

Fig. 5. Representative variations in the dissolved oxygen concentration recorded for zooxanthellae suspensions incubated in the dark in an air-tight micro-chamber; 0 min indicates the initiation of the dark incubation. Zooxanthellae were isolated from Montipora digitata (squares; $1.6 \times 10^{6}$ cells $\mathrm{ml}^{-1}$ ), Pocillopora damicornis (diamonds; $1.3 \times 10^{6}$ cells $\mathrm{ml}^{-1}$ ), Porites cylindrica (inverted triangles; $0.5 \times 10^{6}$ cells $\mathrm{ml}^{-1}$ ), Galaxea fascicularis (circles; $1.2 \times 10^{6}$ cells ml$^{-1}$ ) and massive Porites sp. (triangles; $0.8 \times 10^{6} \mathrm{cells} \mathrm{ml}^{-1}$ ) 
Table 1. Respiration rate $\left(\mathrm{R}_{i} \mathrm{ng} \mathrm{O}_{2} \mathrm{~h}^{-1} 1000 \mathrm{zoox}^{-1}\right)$ and ETSA of zooxanthellae isolated from 5 different coral species; 2 specimens per species

\begin{tabular}{|lccc|}
\hline Species & $\mathrm{R}$ & ETSA & ETSA/R \\
\hline Galaxea fascicularis & 7.66 & 39.3 & 5.13 \\
& 3.32 & 25.9 & 7.80 \\
Porites cylindrica & 5.67 & 35.5 & 6.26 \\
& 3.99 & 23.0 & 5.77 \\
Pocillopora damicornis & 9.38 & 34.6 & 3.69 \\
& 6.23 & 29.4 & 4.72 \\
Montipora digitata & 6.39 & 36.9 & 5.77 \\
Massive Porites sp. & 4.83 & 28.2 & 5.83 \\
Mean \pm SD & 6.35 & 33.9 & 5.34 \\
& 6.80 & 26.1 & 3.83 \\
& $6.06 \pm 1.70$ & $31.3 \pm 4.9$ & $5.2 \pm 1.3$ \\
\hline
\end{tabular}

Porites cylindrica and P. damicornis showed ETSA/R ratios of $3.53 \pm 0.57,2.56 \pm 0.60$ and $3.43 \pm 0.53$, respectively, whereas Montipora digitata and massive Porites sp. exhibited ETSA/R ratios closer to 1, at $1.67 \pm 0.33$ and $1.38 \pm 0.20$, respectively (Fig. 6 ).

The average metabolic rates for each species are shown in Table 3. Light calcification ranged from $6.89 \pm 0.66$ (Pocillopora damicornis) to $34.98 \pm$ $8.54 \mu \mathrm{mol} \mathrm{CaCO}_{3} \mathrm{~h}^{-1} \mathrm{mg}^{-1}$ protein (massive Porites sp.) and dark calcification from $3.70 \pm 0.53$ (P. damicornis) to $21.35 \pm 6.05 \mu \mathrm{mol} \mathrm{CaCO}_{3} \mathrm{~h}^{-1} \mathrm{mg}^{-1}$ protein (massive Porites sp.) for all species. Photosynthesis rates ranged from $0.24 \pm 0.07$ (P. damicornis) to $1.07 \pm$ $0.24 \mathrm{mg} \mathrm{O}_{2} \mathrm{~h}^{-1} \mathrm{mg}^{-1}$ protein (Galaxea fascicularis), while respiration rates ranged from $0.57 \pm 0.08(P$. damicornis) to $1.39 \pm 0.23 \mathrm{mg} \mathrm{O}_{2} \mathrm{~h}^{-1} \mathrm{mg}^{-1}$ protein $(G$. fascicularis). The zooxanthellae density, expressed per mg of host protein, varied among species, with

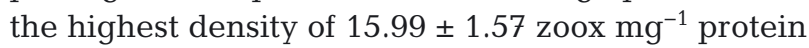
found for G. fascicularis and the lowest of $4.04 \pm$ 0.63 zoox $\mathrm{mg}^{-1}$ protein observed for $P$. damicornis.

Comparing host respiration rates with other metabolic rates, strong correlations were found between respiration and photosynthesis $\left(r^{2}=0.8454, p<0.01\right)$

Table 2. Mean \pm SE ETSA $\left(\mathrm{mg} \mathrm{O}_{2} \mathrm{~h}^{-1} \mathrm{mg}^{-1}\right.$ protein) and calculated respiration rates (R) (mg O $\mathrm{m}_{2} \mathrm{~h}^{-1} \mathrm{mg}^{-1}$ protein) of the host and the zooxanthellae for each coral species (5 replicates per species)

\begin{tabular}{|lrrrc|}
\hline Species & Host ETSA & Host R & Zoox. ETSA & $\begin{array}{c}\text { Contribution } \\
\text { of zoox. to } \\
\text { total R (\%) }\end{array}$ \\
\hline Galaxea fascicularis & $4.68 \pm 0.67$ & $1.39 \pm 0.23$ & $5.41 \pm 0.66$ & $28 \pm 3$ \\
Porites cylindrica & $1.63 \pm 0.26$ & $0.76 \pm 0.18$ & $6.77 \pm 1.38$ & $38 \pm 6$ \\
Pocillopora damicornis & $0.88 \pm 0.18$ & $0.26 \pm 0.06$ & $12.37 \pm 2.40$ & $54 \pm 7$ \\
Montipora digitata & $1.11 \pm 0.23$ & $0.77 \pm 0.21$ & $9.75 \pm 1.79$ & $28 \pm 5$ \\
Massive Porites sp. & $1.78 \pm 0.40$ & $1.28 \pm 0.26$ & $8.48 \pm 1.42$ & $20 \pm 3$ \\
\hline
\end{tabular}

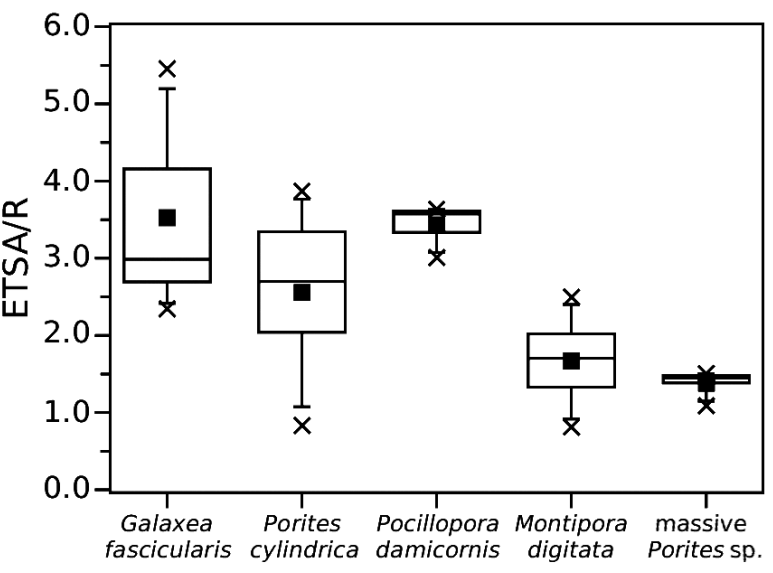

Fig. 6. Box plots of the ETSA/R ratios for the different host species tested. Black squares indicate the average values ( $\mathrm{n}=5$ ); whiskers represent the 5-95\% CIs, $\times$ the minimum and maximum, and the boxes the $25-75 \%$ CIs

and respiration and light calcification $\left(\mathrm{r}^{2}=0.7399, \mathrm{p}<\right.$ 0.01 ), and weaker correlations were detected between respiration and zooxanthellae density $\left(\mathrm{r}^{2}=0.4916\right.$, $\mathrm{p}<0.01)$ and respiration and dark calcification $\left(\mathrm{r}^{2}=\right.$ 0.4947, $\mathrm{p}<0.01$; Fig. 7). Regarding the host ETSA and its correlation with other metabolic rates, the strongest correlation was found between ETSA and zooxanthellae $\left(r^{2}=0.7320, p<0.01\right)$. A weak correlation between photosynthesis and the host ETSA was also found $\left(\mathrm{r}^{2}=0.4687, \mathrm{p}<0.01\right)$. However, calcification (in the light or dark) was not correlated with the host ETSA $\left(\mathrm{r}^{2}=0.2098, \mathrm{p}<0.05\right.$ and $\mathrm{r}^{2}=0.0666, \mathrm{p}=$ 0.21 , respectively; Fig. 8).

\section{DISCUSSION}

\section{ETSA methodology}

After a series of tests, it was possible to identify the optimal procedure for performing ETSA measurements in symbiotic corals. Separation of the host and zooxanthellae fractions was achieved via homogenization using a hand-manipulated Teflon homogenizer and centrifugation. Using this method, the zooxanthellae were released from the host cells. Live mitochondria are usually isolated from animal tissue using a rotor-manipulated homogenizer (Pallotti \& Lenaz 2001). Therefore, we assumed that host mitochondria were not disrupted in this first homogenization step. 
Table 3. Mean \pm SE metabolic rates of the coral colonies during incubation

\begin{tabular}{|c|c|c|c|c|c|}
\hline Species & \multicolumn{2}{|c|}{$\begin{array}{c}\text { Calcification } \\
\left.\text { ( } \mathrm{mmol} \mathrm{CaCO}_{3} \mathrm{~h}^{-1} \mathrm{mg}^{1} \text { protein }\right) \\
\text { Light }\end{array}$} & $\begin{array}{l}\text { Photosynthesis } \\
\left(\mu \mathrm{mol} \mathrm{O} \mathrm{h}^{-1}\right. \\
\left.\mathrm{mg}^{-1} \text { protein }\right)\end{array}$ & $\begin{array}{l}\text { Respiration } \\
\left(\mu \mathrm{mol} \mathrm{O} \mathrm{O}^{-1}\right. \\
\mathrm{mg}^{-1} \text { protein) }\end{array}$ & $\begin{array}{l}\text { Zooxanthellae } \\
\text { density }\left(10^{7} \text { cell }\right. \\
\left.\text { mg }^{-1} \text { protein }\right)\end{array}$ \\
\hline Galaxea fascicularis & $29.27 \pm 2.99$ & $8.63 \pm 2.69$ & $1.07 \pm 0.24$ & $1.39 \pm 0.23$ & $15.99 \pm 1.57$ \\
\hline Porites cylindrica & $18.09 \pm 6.28$ & $7.66 \pm 1.32$ & $0.59 \pm 0.16$ & $1.18 \pm 0.21$ & $6.93 \pm 1.29$ \\
\hline Pocillopora damicornis & $6.89 \pm 0.66$ & $3.70 \pm 0.53$ & $0.24 \pm 0.07$ & $0.57 \pm 0.08$ & $4.04 \pm 0.63$ \\
\hline Montipora digitata & $19.29 \pm 5.12$ & $6.52 \pm 1.71$ & $0.50 \pm 0.16$ & $1.07 \pm 0.30$ & $5.60 \pm 1.30$ \\
\hline Massive Porites sp. & $34.98 \pm 8.54$ & $21.35 \pm 6.05$ & $0.93 \pm 0.22$ & $1.60 \pm 0.30$ & $10.61 \pm 2.34$ \\
\hline
\end{tabular}

Sonication produced better results in terms of ETSA recovery than mechanical homogenization, similar to previous results (Broberg 1985). The homogenization buffer used in this study differs from that described in the original methods mainly due to the addition of $10 \mathrm{mmol}^{-1}$ EDTA. The specific effect of EDTA on host activity is not yet understood, though it may be caused by a greater amount of divalent cations (e.g. $\mathrm{Ca}^{2+}$, metals) in the host fraction (than in the zooxanthellae fraction) interfering with the assay. Divalent cations are known co-factors of phospholipase, which may damage the isolated ETS (Pallotti \& Lenaz 2001). Therefore, the final homogenization buffer chosen consisted of $1.5 \mathrm{mg} \mathrm{ml}^{-1} \mathrm{PVP}, 75 \mathrm{mmol} \mathrm{l}^{-1} \mathrm{MgSO}_{4}$, $10 \mathrm{mmol}^{-1}$ EDTA and $10 \mathrm{~g} \mathrm{l}^{-1} \mathrm{NaCl}$ in phosphate buffer at $50 \mathrm{mmol} \mathrm{l}^{-1}$, adjusted to $\mathrm{pH} 8.5$.
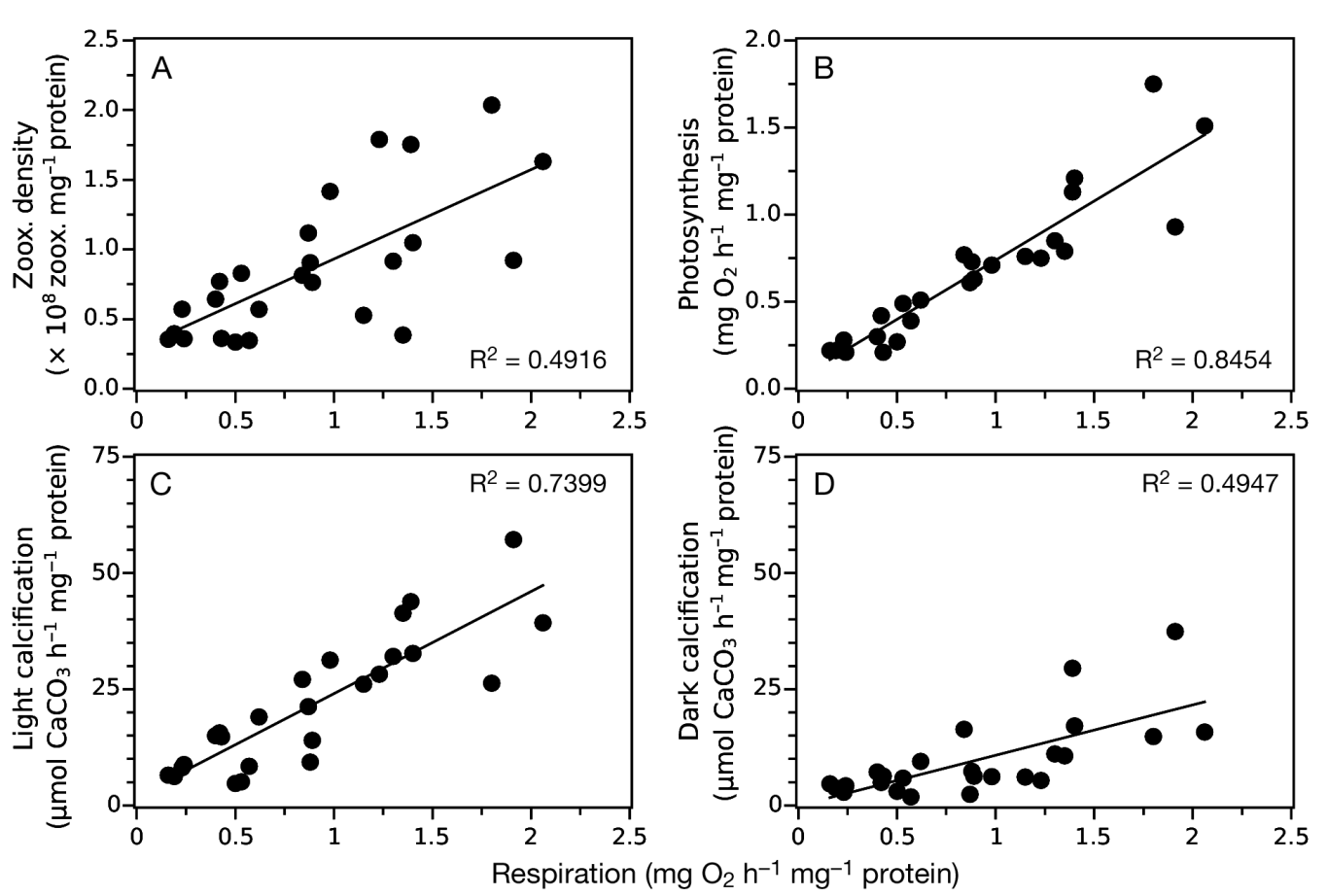

Fig. 7. Correlation of host respiration with (A) zooxanthellae density, (B) photosynthesis, (C) light calcification and (D) dark calcification. Each point represents the values for one specimen of either Galaxea fascicularis, Porites cylindrica, Pocillopora damicornis, Montipora digitata or the massive Porites sp. Straight lines indicate the linear regression by the least square method. The $\mathrm{R}^{2}$ for each regression is indicated on the respective plot
For this study, the substrate concentrations required to reach saturation of the ETS differed slightly from previously reported concentrations. The addition of NADPH strongly increased the ETSA of the zooxanthellae. This result can be interpreted in different ways. First, the zooxanthellae presented a higher microsomal ETSA, which utilizes NADPH, than did the hosts, thus indicating that the microsomal ETS is a major site of energy conversion and oxygen consumption in the zooxanthellae. High microsomal ETSAs have also been shown for the unicellular green alga Dunaliellae tertiolecta (Kenner \& Ahmed 1975a). Second, the zooxanthellae fraction exhibited high transhydrogenase activity, which transfers electrons from NADPH and NADH. However, because NADH was already at saturation, this interpretation can be re- 

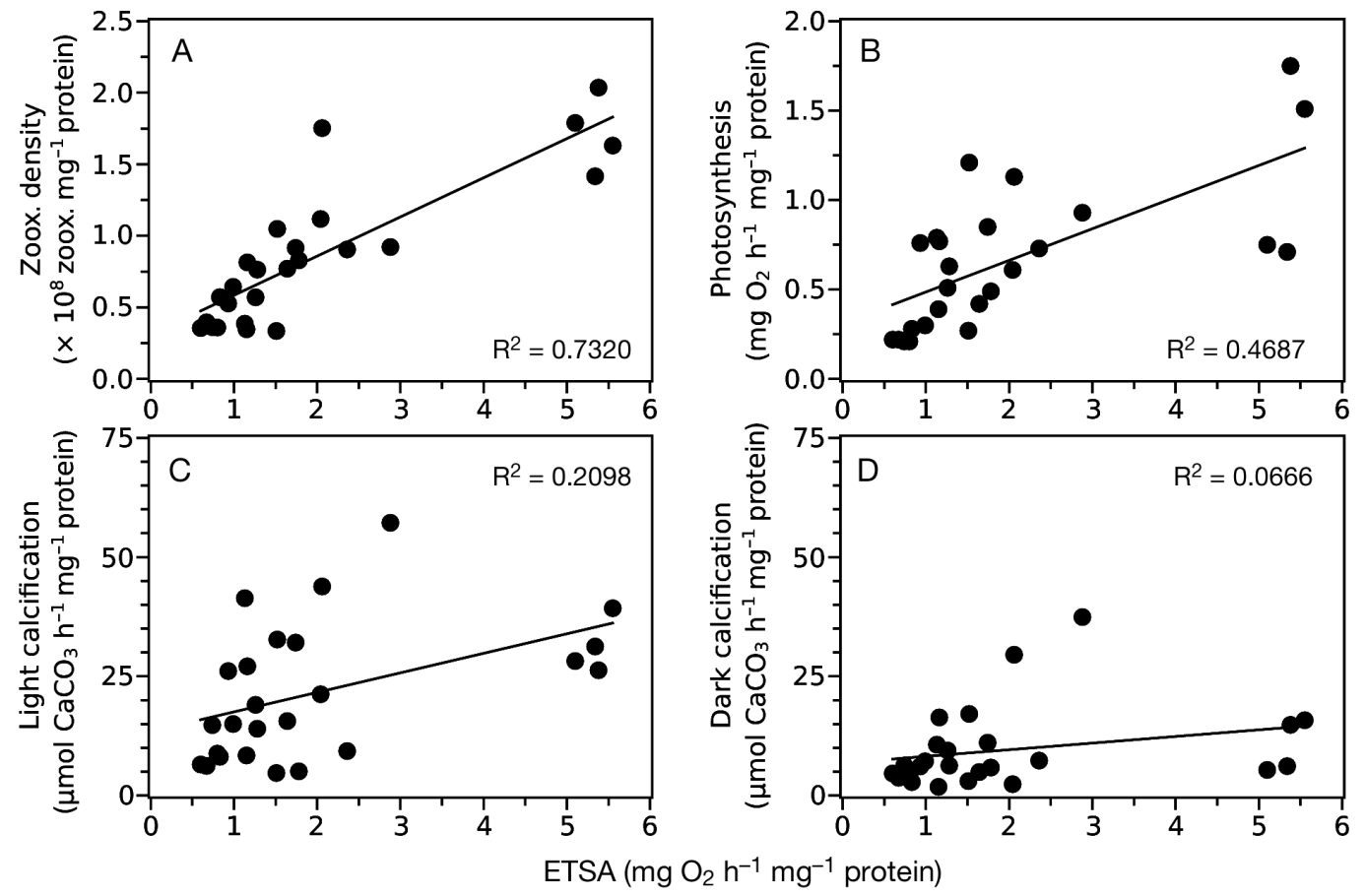

Fig. 8. Correlation of ETSA with (A) zooxanthellae density, (B) photosynthesis, (C) light calcification and (D) dark calcification. Each point represents the values for one specimen of either Galaxea fascicularis, Porites cylindrica, Pocillopora damicornis, Montipora digitata or the massive Porites sp. Straight lines represent the linear regression by the least square method. The $\mathrm{R}^{2}$ for each regression is indicated on the respective plot

jected. Third, the zooxanthellae mitochondrial ETS can also use NADPH as an electron donor (Savenkoff et al. 1995a). The addition of succinate did not increase the measured ETSA in either fraction, and even had a small inhibitory effect. A similar impact has been observed on the ETSA of Daphnia (Owens \& King 1975) and zooplankton (Simičič \& Brancelj 2004), even though a positive effect was shown in the original protocol (Packard 1971). Therefore, the selected substrate mixture was NADH at $1.5 \mathrm{mmol} \mathrm{l}^{-1}$ and $\mathrm{NADPH}$ at $0.15 \mathrm{mmol}^{-1}$. The activity was proportional to the volume of homogenates used in the assay up to $600 \mu \mathrm{l}$ with a $20 \mathrm{~min}$ incubation. For samples with very high activity, the reaction may be become substrate limited, and a lower sample volume than the chosen volume of $300 \mu \mathrm{l}$ or shorter incubation time should therefore be considered in such a case.

An optimum $\mathrm{pH}$ of 8.5 was identified. The same optimum $\mathrm{pH}$ has been found for other organisms (Kenner \& Ahmed 1975a, Christensen \& Packard 1979), which can be explained by the similar $\mathrm{pH}$ dynamics observed in the mitochondria across a variety of organisms and their general alkaline character (Takahashi et al. 2001, Balut et al. 2008, Orij et al. 2009). Although the buffering capacity of phosphate buffer is weak at $\mathrm{pH} 8.5$, the measurements of Owens \& King (1975) and our own measurements showed very little variation in $\mathrm{pH}$ within the assay mixture, with $\mathrm{pH}$ differences of $<0.1$ being recorded.

Across the range of temperatures inhabited by scleractinian corals, from 20 to $35^{\circ} \mathrm{C}$, activity increased with temperature. Simičič \& Brancelj (2004) showed maximum ETSA of different Daphnia hybrids at temperatures corresponding to their naturally occurring temperature range. The dependence of the ETSA on temperature may explain the observed increase in respiration with temperature for some species (Edmunds 2004, Colombo-Pallotta et al. 2010). However, these studies only showed the effects of temperature on ETSA during the assay, and caution should be used when interpreting results from temperature stress experiments, where corals are incubated for long periods at elevated temperatures $\left(>30^{\circ} \mathrm{C}\right)$, and damage to the mitochondrial ETS may occur (Moller 2001, Taylor et al. 2004).

The obtained $E_{\mathrm{a}}$ values were 47.2 and $30.3 \mathrm{~kJ} \mathrm{~mol}^{-1}$ for the host and zooxanthellae, respectively, which are lower than those previously reported for zooplankton of $65.9 \mathrm{~kJ} \mathrm{~mol}^{-1}$ (Packard et al. 1975) and $57.6 \mathrm{~kJ} \mathrm{~mol}^{-1}$ (Simičič \& Brancelj 2004). The temperature chosen for our assay was $25^{\circ} \mathrm{C}$. At this temperature, we were able to obtain a strong signal, and the reaction remained linear for $20 \mathrm{~min}$. Higher or lower temperatures may be used, but the linearity of the 
reaction should be checked and the incubation time modified accordingly. The $E_{\text {a }}$ presented here can be employed to correct the ETSA using the Arrhenius law (Packard et al. 1975). This can be particularly useful for estimating ETSA in the field when the temperature at which the assay is performed differs from the in situ temperature.

\section{Respiration and ETSA of isolated zooxanthellae}

The ETSA/R ratios were 5.2 on average for the zooxanthellae. This ratio falls within the ETSA/R range of 5.6 to 9.4 reported for 10 species of phytoplankton (Kenner \& Ahmed 1975b), and is higher than those reported for zooplankton, which range between 1.0 and 2.0 (Hernández-Leó \& Gómez 1996). The high ETSA/R ratio of phytoplankton suggests that photosynthetic organisms do not exploit their full respiratory potential in the dark, due to substrate limitation (Peñuelas et al. 1988). Higher respiration rates for phytoplankton and corals have been shown previously using light/dark shift methods with microsensors (Jørgensen et al. 1985, Kühl et al. 1995, Al-Horani et al. 2003). Our results support the idea that measuring the respiration rates of the zooxanthellae based on $\mathrm{O}_{2}$ consumption in the dark may have led to underestimation of the daytime respiration rates of zooxanthellae and, consequently, of the coral holobiont.

\section{ETSA/R ratio and host respiration}

An ETSA/R ratio of 1 is the theoretical minimum value (Packard \& Gómez 2008). Considerable intraspecific and interspecific variation in the ETSA/R ratio has been observed for coral hosts. The higher ratios reported here may be due to lower-than-optimal respiration rates. Indeed, coral respiration depends on numerous factors, and sub-optimal conditions during measurement, such as confinement stress, limited availability of food, low light conditions and therefore low photosynthesis rates, or conditions to which corals are not acclimated, may decrease measured respiration rates. In such cases, the measured respiration rates will be lower than the potential rates represented by the ETSA, as the limiting factor for respiration is not the number of ETS chains present, but the availability of the substrate (NADH). Therefore, we suggest that the high ratios observed in some specimens of the different species tested were due to respiration in the dark being substrate limited in our experiment. The ratios measured under opti- mal conditions may not differ significantly among species, and as respiration is not limited, coral hosts may show an ETSA/R ratio closer to 1 , as was the case for some of our specimens, especially in the massive Porites sp. and Montipora digitata.

The ETSA/R ratios reported here show that the respiration rates of hosts in the dark could theoretically increase in light by a factor ranging from 1.38 to 3.53 , with an average of 2.5. A ratio close to 1 , as was found for some specimens, indicates that the coral hosts were reaching their maximum respiration rates in the dark. Therefore, an increase in respiration, which would increase the amount of energy available under light conditions, would not be possible.

Due to the small amount of zooxanthellae compared with host tissue and/or their high ETSA/R ratios, zooxanthellae respiration represents less than half of the total respiration in the dark. If zooxanthellae increase their respiration rates by a factor of 5.2 in light, as shown by their ETSA/R ratios, the amount of respiration contributed by the zooxanthellae may become higher than the amount attributed to the host. Taken together, if the zooxanthellae increase their respiration by a factor of 5.2 in the light and the host by factor of 2.5 , the total holobiont respiration would increase by a factor of 3.4. This maximum possible increase in the respiration of the holobiont predicted by ETSA/R is lower than that reported from microsensor studies, which have shown an increase of respiration by a factor of 7 to 12 for whole corals (Kühl et al. 1995, Al-Horani et al. 2003). The higher respiration in light recorded using microsensors may be due to the extreme location specificity of such measurements, which measure variation in oxygen only in the most external tissues (oral layer), where zooxanthellae are present in high numbers compared with deeper tissue. However, the reported increase of 7 to 12 times is higher than the ETSA/R ratio of the zooxanthellae. Further investigation of the increased respiration observed under light in the coral holobiont is still required.

ETSA was correlated with the zooxanthellae density. This result suggests an adaptation of the potential respiration rate to the density of zooxanthellae. The translocation of carbon from the zooxanthellae represents up to $90 \%$ of the total carbon requirement of corals (Edmunds \& Davies 1986, Leletkin 2000). Thus, organic matter produced by the zooxanthellae serves as the main substrate source for respiration. Therefore, the zooxanthellae density constrains the amount of substrate available for host respiration. Consequently, we can hypothesize that the amount of ETS in corals is adapted to the amount of substrate 
available and therefore to the zooxanthellae density. The ETSAs measured for micro-picoplankton in the open ocean have been found to be correlated with the amount of organic carbon available for respiration (Kenner \& Ahmed 1975b, Savenkoff et al. 1995b, Lefevre et al. 1996, Arístegui et al. 2005) and deepocean ETSAs can be equated with new production in surface waters (Packard et al. 1988). Similarly, in the case of symbiotic corals, the host ETSA may be equivalent to the rate of carbon translocation from the zooxanthellae to the host.

\section{ETSA, respiration and calcification}

In the present study, host respiration was correlated with calcification both in the light and in the dark. This is not unexpected because host respiration is the source of ATP, which is used, in part, for calcification (Allemand et al. 2004). Energy in the form of ATP is required for up-regulation of the $\mathrm{pH}$ at the calcification site, which is essential for the formation of aragonite. Direct measurements with microsensors have indicated $\mathrm{pH}$ values at the calcification site as high as 9.3 (Al-Horani et al. 2003), which was recently confirmed using boron isotopes in the skeleton as a proxy (McCulloch et al. 2012) and live imaging of the subcallicoblast $\mathrm{pH}$ (Venn et al. 2009, 2011).

In our experiment, calcification was enhanced in light. As discussed earlier, an increase in host respiration under light may not be possible, and the mechanism involving the titration of $\mathrm{H}^{+}$, pumped into the coelenteron by $\mathrm{OH}^{-}$produced from photosynthesis (Furla et al. 2000), may therefore be the main factor enhancing calcification under light. ETSA was not correlated with calcification, and the ETSA/R ratios were not correlated with the ratio between light and dark calcification. As the high ETSA/R ratio obtained suggests that host respiration, and therefore energy production, was substrate limited, the amount of ETS enzymes available was not the limiting factor. Under optimal conditions, where host respiration increases up to the potential respiration, calcification and ETSA may be correlated.

The typical relationship observed between photosynthesis and calcification may be indirect. The photosynthetic rate limits the host respiration rate through the supply of the required substrate. Consequently, the production of ATP is limited, which in turn, limits the Ca-ATPase activity and the $\mathrm{pH}$ upregulation required for calcification. An alternative substrate source for respiration may be the organic matter ingested and digested by the coral, i.e. hetero- trophy. The calcification rates of fed corals are higher than those of starved corals, showing the importance of heterotrophy for coral growth (Ferrier-Pagès et al. 2003, Houlbrèque et al. 2003, Houlbrèque \& FerrierPagès 2009). Dark calcification has been reported to be especially simulated by feeding compared with light calcification (Houlbrèque et al. 2004). Heterotrophy provides the substrate required for respiration, especially in the dark, increasing the amount of ATP that can be produced by the ETS and used for calcification. It also provides the substrate essential for the construction of the organic matrix.

Different parameters, such as light, food availability and temperature, may influence the availability of the substrate for host respiration and/or the rate at which $\mathrm{O}_{2}$ and therefore ATP is produced, limiting

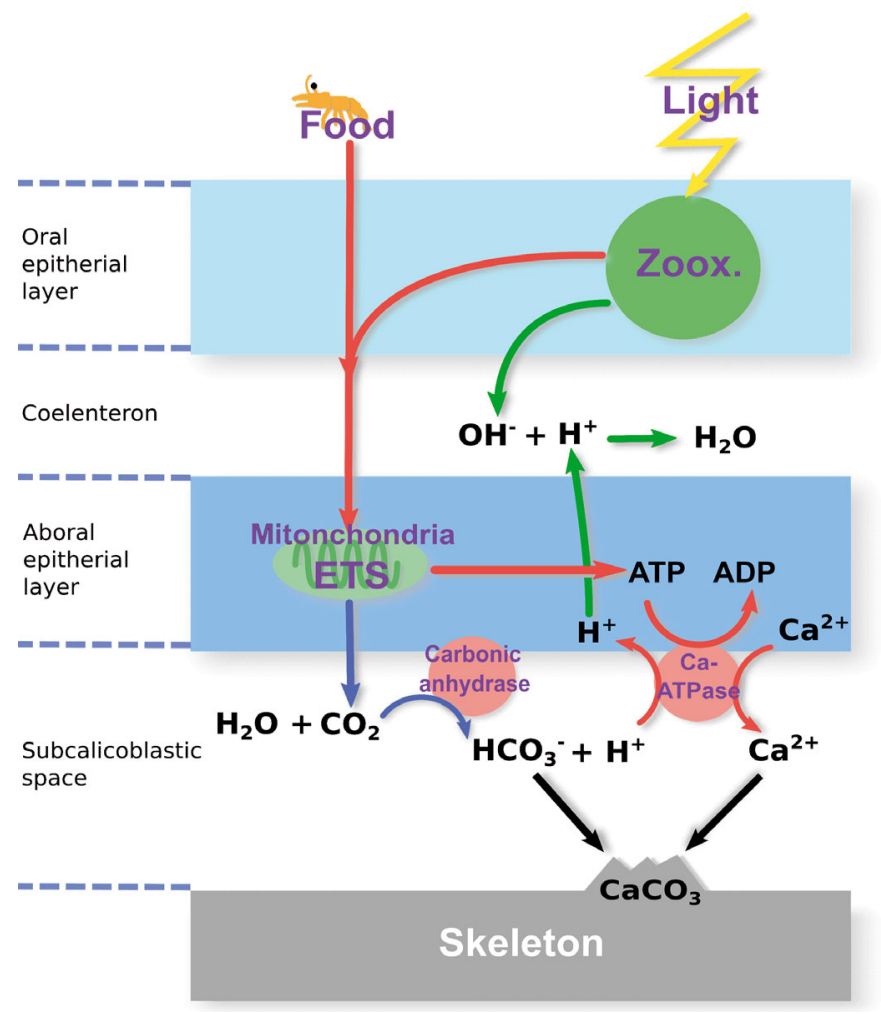

Fig. 9. Calcification model based on Allemand et al. (2004). Substrate limitation of calcification is shown by the red arrows: the calcification rate is limited by the availability of the substrate for respiration, and the substrate may be acquired via heterotrophy or translocation from the zooxanthellae. Thus, the respiration rate determines the amount of energy produced by the mitochondrial ETS and, in turn, the amount of ATP available. This limits the activity of Ca-ATPase, which regulates the $\mathrm{pH}$ in the subcalicoblastic space. Light enhancement of calcification (green arrows) is due to the titration of protons in the coelenteron by $\mathrm{OH}^{-}$produced from photosynthesis. The blue arrows represent the $\mathrm{CO}_{2}$ supplied for calcification by respiration. $\mathrm{CO}_{2}$ is then converted to $\mathrm{HCO}_{3}{ }^{-}$by carbonic anhydrase. Black arrows represent the precipitation of calcium carbonates 
calcification. If host respiration is not limited by substrate availability, it will be limited by the ETSA, which will determine the energy available for calcification. Thus, we propose a 'respiration-limited calcification model' based on the model described in Allemand et al. (2004) and the trans-calcification model of McConnaughey (1997). In our model, illustrated in Fig. 9, respiration occupies a central region, as it determines calcification rates, and it furthermore produces $\mathrm{CO}_{2}$, which is then converted into carbonate by carbonic anhydrase and used for calcification (Moya et al. 2008). In this model, the enhancement of calcification by light is only due to the increase in $\mathrm{OH}^{-}$in the coelenteron, as an increase in host respiration under light may not be possible due to the low ETSA/R ratio exhibited by coral hosts.

The proposed method for the measurement of ETSA in symbiotic corals provides a new and useful tool for the study of coral physiology. The obtained ETSA/R values showed that the zooxanthellae may increase their respiration in light by a factor of 5.2, while that of the coral host may increase by a factor of 2.5. Some host specimens showed an ETSA/R ratio of 1 , suggesting that the higher ETSA/R values observed for other specimens may be due to respiration being limited by a factor other than the ETS at the time of measurement. Further research will be needed to determine whether the hosts can show increased respiration in light, but our results suggest that an increase in host respiration in light may not explain the enhancement of calcification in light. We demonstrated that host respiration is correlated with calcification. Taken together, our results suggest that host respiration, limited by substrate availability or the ETSA, determines calcification rates.

Acknowledgements. The authors thank 3 anonymous reviewers for helpful comments that improved the final version of the manuscript and Prof. M. Wada for his suggestion on undertaking this research. This research was supported by the International Research Hub Project for Climate Change and Coral Reef/Island Dynamics at the University of the Ryukyus and a Grant-in-Aid for Scientific Research on Innovative Areas entitled 'Coral reef science for symbiosis and coexistence of human and ecosystem under combined stresses' (no. 20121003) of the Ministry of Education, Culture, Sports, Science and Technology (MEXT), Japan.

\section{LITERATURE CITED}

Al-Horani F, Al-Moghrabi S, De Beer D (2003) The mechanism of calcification and its relation to photosynthesis and respiration in the scleractinian coral Galaxea fascicularis. Mar Biol 142:419-426

- Allemand $D$, Ferrier-Pagès $C$, Furla $P$, Houlbrèque $F$ and others (2004) Biomineralisation in reef-building corals: from molecular mechanisms to environmental control. C R Palevol 3:453-467

Arístegui J, Agustí S, Middelburg JJ, Duarte CM (2005) Respiration in the mesopelagic and bathypelagic zones of the oceans. In: del Giorgio P, Williams P (eds) Respiration in aquatic ecosystems. Oxford University Press, Oxford, p 181-205

Balut C, vandeVen M, Despa S, Lambrichts I, Ameloot M, Steels P, Smets I (2008) Measurement of cytosolic and mitochondrial $\mathrm{pH}$ in living cells during reversible metabolic inhibition. Kidney Int 73:226-232

Bamstedt U (1980) ETS activity as an estimator of respiratory rate of zooplankton populations. The significance of variations in environmental factors. J Exp Mar Biol Ecol 42: 267-283

Barnes DJ, Chalker BE (1990) Calcification and photosynthesis in reef-building corals and algae. In: Dubinsky Z (ed) Ecosystems of the world. Elsevier Science Publisher, Amsterdam, p 109-131

Barnes D, Taylor D (1973) In situ studies of calcification and photosynthetic carbon fixation in the coral Montastrea annularis. Helgol Mar Res 24:284-291

Broberg A (1985) A modified method for studies of electron transport system activity in freshwater sediments. Hydrobiologia 120:181-187

Cammen L, Corwin S, Christensen JP (1990) Electron transport system (ETS) activity as a measure of benthic macrofaunal metabolism. Mar Ecol Prog Ser 65:171-182

Christensen JP, Packard TT (1979) Respiratory electron transport activities in phytoplankton and bacteria: comparison of methods. Limnol Oceanogr 24:576-583

Colombo-Pallotta MF, Rodríguez-Román A, Iglesias-Prieto R (2010) Calcification in bleached and unbleached Montastraea faveolata: evaluating the role of oxygen and glycerol. Coral Reefs 29:899-907

Edmunds PJ (2004) Effect of elevated temperature on aerobic respiration of coral recruits. Mar Biol 146:655-663

$>$ Edmunds PJ, Davies PS (1986) An energy budget for Porites porites (Scleractinia). Mar Biol 92:339-347

Ferrier-Pagès C, Witting J, Tambutte E, Sebens KP (2003) Effect of natural zooplankton feeding on the tissue and skeletal growth of the scleractinian coral Stylophora pistillata. Coral Reefs 22:229-240

Furla P, Bénazet-Tambutté S, Jaubert J, Allemand D (1998) Functional polarity of the tentacle of the sea anemone Anemonia viridis: role in inorganic carbon acquisition. Am J Physiol 274:R303-R310

Furla P, Galgani I, Durand I, Allemand D (2000) Sources and mechanisms of inorganic carbon transport for coral calcification and photosynthesis. J Exp Biol 203:3445-3457

Gattuso J, Allemand D (1999) Photosynthesis and calcification at cellular, organismal and community levels in coral reefs: a review on interactions and control by carbonate chemistry. Am Zool 183:160-183

Gattuso J, Pichon M, Delesalle B, Canon C, Frankignoulle M (1996) Carbon fluxes in coral reefs. I. Lagrangian measurement of community metabolism and resulting air-sea $\mathrm{CO}_{2}$ disequilibrium. Mar Ecol Prog Ser 145:109-121

> Gattuso JP, Reynaud-Vaganay S, Furla P, Romaine-Lioud S, Jaubert J, Bourge I, Frankignoulle M (2000) Calcification does not stimulate photosynthesis in the zooxanthellate scleractinian coral Stylophora pistillata. Limnol Oceanogr 45:246-250

Goreau TF (1959) The physiology of skeleton formation in corals. I. A method for measuring the rate of calcium deposition by corals under different conditions. Biol Bull 116:59-75 
Hernández-Leó S, Gómez M (1996) Factors affecting the respiration/ETS ratio in marine zooplankton. J Plankton Res 18:239-255

Houlbrèque F, Ferrier-Pagès C (2009) Heterotrophy in tropical scleractinian corals. Biol Rev Camb Philos Soc 84:1-17

Houlbrèque F, Tambutté E, Ferrier-Pagès C (2003) Effect of zooplankton availability on the rates of photosynthesis, and tissue and skeletal growth in the scleractinian coral Stylophora pistillata. J Exp Mar Biol Ecol 296:145-166

Houlbrèque $F$, Tambutté É, Allemand D, Ferrier-Pagès C (2004) Interactions between zooplankton feeding, photosynthesis and skeletal growth in the scleractinian coral Stylophora pistillata. J Exp Biol 207:1461-1469

> Jørgensen BB, Erez J, Revsbech NP, Cohen Y (1985) Symbiotic photosynthesis in a planktonic foraminiferan, Globeriginoides sacculifer (Brady), studied with microelectrodes. Limnol Oceanogr 30:1253-1267

Kenner RA, Ahmed SI (1975a) Measurements of electron transport activities in marine phytoplankton. Mar Biol 33: 119-127

Kenner RA, Ahmed SI (1975b) Correlation between oxygen utilization and electron transport activity in marine phytoplankton. Mar Biol 33:129-133

Kühl M, Cohen Y, Dalsgaard T, Jorgensen BB, Revsbech NP (1995) Microenvironment and photosynthesis of zooxanthellae in scleractinian corals studied with microsensors for $\mathrm{O}_{2}, \mathrm{pH}$ and light. Mar Ecol Prog Ser 117:159-172

Lefevre D, Denis M, Lambert C (1996) Is DOC the main source of organic matter remineralization in the ocean water column? J Mar Syst 7:281-291

Leletkin V (2000) The energy budget of coral polyps. Russ J Mar Biol 26:389-398

Marshall AT (1996) Calcification in hermatypic and ahermatypic corals. Science 271:637-639

Martínez I, Gómez M, Packard TT (2010) Potential respiration is a better respiratory predictor than biomass in young Artemia salina. J Exp Mar Biol Ecol 390:78-83

McConnaughey T (1997) Calcification generates protons for nutrient and bicarbonate uptake. Earth Sci Rev 42:95-117

McConnaughey TA, Adey WH, Small AM (2000) Community and environmental influences on reef coral calcification. Limnol Oceanogr 45:1667-1671

McCulloch M, Falter J, Trotter J, Montagna P (2012) Coral resilience to ocean acidification and global warming through $\mathrm{pH}$ up-regulation. Nature Climate Change 2: 623-627

Moller IM (2001) Plant mitochondria and oxidative stress: electron transport, NADPH turnover, and metabolism of reactive oxygen species. Annu Rev Plant Physiol Plant Mol Biol 52:561-591

Moya A, Tambutté S, Tambutté E, Zoccola D, Caminiti N, Allemand D (2006) Study of calcification during a daily cycle of the coral Stylophora pistillata: implications for 'light-enhanced calcification'. J Exp Biol 209:3413-3419

Moya A, Tambutté S, Bertucci A, Tambutté E and others (2008) Carbonic anhydrase in the scleractinian coral Stylophora pistillata: characterization, localization, and role in biomineralization. J Biol Chem 283:25475-25484

> Olanczukneyman K, Vosjan J (1977) Measuring respiratory electron-transport-system activity in marine sediment. Neth J Sea Res 11:1-13

Orij R, Postmus J, Ter Beek A, Brul S, Smits GJ (2009) In vivo measurement of cytosolic and mitochondrial $\mathrm{pH}$ using a pH-sensitive GFP derivative in Saccharomyces cerevisiae reveals a relation between intracellular $\mathrm{pH}$ and growth. Microbiology 155:268-78

$>$ Owens TG, King FD (1975) The measurement of respiratory electron-transport-system activity in marine zooplankton. Mar Biol 30:27-36

Packard TT (1971) The measurement of respiratory electron-transport activity in marine phytoplankton. J Mar Res 29:235-244

Packard TT, Gómez M (2008) Exploring a first-principlesbased model for zooplankton respiration. ICES J Mar Sci 65:371-378

Packard TT, Devol A, King F (1975) The effect of temperature on the respiratory electron transport system in marine plankton. Deep-Sea Res Oceanogr Abs 22:237-249

Packard TT, Denis M, Rodier M, Garfield P (1988) Deepocean metabolic $\mathrm{CO}_{2}$ production: calculations from ETS activity. Deep-Sea Res A 35:371-382

Pallotti F, Lenaz G (2001) Isolation and subfractionation of mitochondria from animal cells and tissue culture lines. In: Wilson L, Matsudaira P (eds) Methods in cell biology, Vol 65 Mitochondria. Academic Press, San Diego, CA, p 2-31

> Peñuelas J, Murillo J, Azcón-Bieto J (1988) Actual and potential dark respiration rates and different electron transport pathways in freshwater aquatic plants. Aquat Bot 30:353-362

R Development Core Team (2011) R: A Language and Environment for Statistical Computing. R Foundation for Statistical Computing, Vienna

> Relexans JC (1996a) Measurement of the respiratory electron transport system (ETS) activity in marine sediments: state-of-the-art and interpretation. I. Methodology and review of literature data. Mar Ecol Prog Ser 136:277-287

Relexans JC (1996b) Measurement of the respiratory electron transport system (ETS) activity in marine sediments: state-of-the-art and interpretation. II. Significance of ETS activity data. Mar Ecol Prog Ser 136:289-301

Savenkoff C, Packard TT, Rodier M, Gérinno M, Lefèvre D, Denis M (1995a) Relative confribution of dehydrogenases to overall respiratory ETh activity in some marine organisms. J Plankton Res 17:1593-1604

Savenkoff C, Zina AFV, Chanut J, Gratton Y (1995b) Respiratory activity and $\mathrm{CO}_{2}$ production rates of microorganisms in the lower St Lawrence Estuary. Cont Shelf Res 15: 613-631

Simičič T, Brancelj A (2004) Respiratory electron transport system (ETS) activity as an estimator of the thermal tolerance of two Daphnia hybrids. J Plankton Res 26:525-534

Simkiss K (1964) Phosphates as crystal poisons of calcification. Biol Rev 39:487-504

St-Amand L, Gagnon R, Packard TT, Savenkoff C (1999) Effects of inorganic mercury on the respiration and the swimming activity of shrimp larvae, Pandalus borealis. Comp Biochem Physiol C Pharmacol Toxicol Endocrinol 122:33-43

Takahashi A, Zhang Y, Centonze E, Herman B (2001) Measurement of mitochondrial $\mathrm{pH}$ in situ. Biotechniques 30: 804-808, 810, 812 passim

Taylor NL, Day DA, Millar AH (2004) Targets of stressinduced oxidative damage in plant mitochondria and their impact on cell carbon/nitrogen metabolism. J Exp Bot 55:1-10

Venn AA, Tambutté E, Lotto S, Zoccola D, Allemand D, Tambutté S (2009) Imaging intracellular $\mathrm{pH}$ in a reef coral and symbiotic anemone. Proc Natl Acad Sci USA 106:16574-16579

Venn AA, Tambutté E, Holcomb M, Allemand D, Tambutté $\mathrm{S}$ (2011) Live tissue imaging shows reef corals elevate ph under their calcifying tissue relative to seawater. PloS ONE 6:e20013 